\title{
On the Rationality of Will in James and Husserl
}

\author{
Susi Ferrarello
}

\section{OpenEdition}

\section{Journals}

Electronic version

URL: http://journals.openedition.org/ejpap/946

DOI: 10.4000/ejpap.946

ISSN: 2036-4091

\section{Publisher}

Associazione Pragma

\section{Electronic reference}

Susi Ferrarello, "On the Rationality of Will in James and Husserl », European Journal of Pragmatism and American Philosophy [Online], II-1 | 2010, Online since 01 July 2010, connection on 02 May 2019. URL: http://journals.openedition.org/ejpap/946 ; DOI : 10.4000/ejpap.946

This text was automatically generated on 2 May 2019.

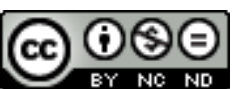

Author retains copyright and grants the European Journal of Pragmatism and American Philosophy right of first publication with the work simultaneously licensed under a Creative Commons AttributionNonCommercial-NoDerivatives 4.0 International License. 


\title{
On the Rationality of Will in James and Husserl
}

\author{
Susi Ferrarello
}

\section{Introduction}

1 Phenomenology and pragmatism are philosophical movements similar and contrasting at the same time. Some scholars wonder about the possibility of a common domain, while others discuss the risk of their resemblances. ${ }^{1}$ Even if these movements are different in tradition and place, it seems to be possible to discover not only an encounter but even a connection between them. As Benoist remarked, in fact, there is a fundamental likeness between their methods which can even lead to recognizing them as two "phenomenologies." Indeed, both look at 'things themselves,' exploiting a similar descriptive approach .

2 In the context of American philosophy a sort of dialogue has taken place over the years, thanks to an understanding of differing pathways as well as an understanding of the common background of philosophic history. Though the role of phenomenology is not predominant in American philosophy, it is becoming greater than in past years. Toward the end of the 1950's Gurtwisch lamented: "As far as the situation in United States is concerned, the unfortunate fact of the matter is that Husserl's writings are hardly studied at all [...]. Phenomenology is not permitted to exert the invigorating influence it might have on American philosophy, which thus deprives itself of the vitalization, it might derive from the philosophic substance and radicalism of Husserl's work." 'Gurtwisch was the first philosopher who presented the radicalism of phenomenology as a heuristic instrument for revitalizing the main currents of American thought. Indeed, phenomenology was construed not as a redoing of what masters did, but as a creative appropriation of a framework and a method, which is concerned with the crucial and traditional philosophic problems. Conversely, in the article which appeared in April 1973 in the Monist, Pragmatism Reconsidered, pragmatism was described as the bearer of an 
unsystematic welter of philosophic insights, from which various movements could draw on in showing that the pragmatists were really realists or idealists, logical or positivists and now budding phenomenologists. ${ }^{3}$

3 Therefore, both phenomenology and pragmatism are pluralistic approaches to doing philosophy and they can be useful to fill in each other's lacks. Their convergences as well their divergences can be explored and allowed to develop, before we attempt to establish the clear and irrevocable lines of demarcation which necessarily separate them. As Edie wrote, this process contrives to lay bare a unique philosophic network of complexity and it can annihilate a delicate, elusive network with its own philosophic strength. ${ }^{4}$

We believe that a firm link between phenomenology and pragmatism takes its origin from a Husserlian reading of James. Indeed, it is historically attested that Husserl read the Principles and perhaps the critical 35 pages of the summary elaborated by Marty. Therefore, James seems to have exerted a certain influence on Husserlian work. Even before the flourishing of phenomenology, it is likely that the direction of Husserl's analysis toward what he called the 'phenomenological,' was affected by the Principles. ${ }^{5}$ As it concerns our topic, it is worthwhile to emphasize that Husserl and James carried on similar approaches to the study of consciousness. Both presented an idea of will in which the epistemological layer seems to be predominant and thus to prevent any moral deed. By inference, their description of will lowers the range of action of freedom. Therefore, we are going to make a comparison between Jamesian and Husserlian analysis of will as presented in chapter XXVI of James' Principles and in Husserl's ethical lectures of 1914. Singling out the points of uniqueness of the two currents, we will be able to study the common network more deeply, as well as the differences between the two philosophers.

\section{Husserl and James}

In 1891/92 Husserl took a class on psychology and on that occasion he read the Principles for the first time. That probably came about as a result of advice from Stumpf, who encountered James when he was in Europe in 1882. Though Husserl admitted being able to understand just a portion of the volume, he admired the audacity and originality of Jamesian analysis. In May 1894 he came back to Principles, while he was working on his logic and its elementary concepts and he praised the Jamesian effort of "depsychologizing psychology." At that time he had planned to publish a series of articles in the Philosophishe Monatshefte, but he published only the first and decided to wait to see what James had done, before publishing the others. ${ }^{6}$ The next article is probably his Psychological Studies for Elementary Logic.

5 The subjects that mostly caught Husserl's interest were those about Intention Wahrnehmende. As it is possible to see from his library, he read above all chapters 24, 25 and 26 of the second volume of Principles and the article entitled Knowing of Things Together. He found James' psychology "einige Blitz" and he recognized some similarities with his work. He even affirmed that his "Identifikation von Interesse und Wille" tied in with his "uralten Vorlesungen über Psychologie." Therefore Husserl was the first person to make a comparison between his analysis and that of James. ${ }^{9}$ There is in fact a continuity between the two. Although Principles and the ethical lectures of 1914 are elaborated from two different perspectives, they almost reach common conclusions. In our opinion both James and Husserl identified the will as a rational faculty, which is characterized above all by an epistemological layer. This involves some difficulties 
regarding the notion of freedom. Indeed, if the will can act only when it knows what it can do, its fiat is always related to the knowledge and consequently its freedom to act is always connected to the epistemological reason of the subject. The will and its freedom need an epistemological basis to know what it is right to do. In the following sections we will see how this thesis is developed.

\section{What is Consciousness?}

The study of consciousness is the main key to figuring out how Husserl and James conceive of the will. To have an overall idea about it, it is necessary to explain its structure (if it has one) and its relationship with the outside world. Both philosophers construe consciousness as a realm of pure experience.

7 According to James, consciousness is a neutral unit, that we might be able to describe with minimum assumptions like "Thought goes on" or "It thinks." ${ }^{10}$ As he wrote: "I believe that 'consciousness,' once it has evaporated to this estate of pure diaphaneity, is on the point of disappearing altogether. It is the name of a nonentity, and has no right to a place among first principles." ${ }^{11}$ The underlying statement is that consciousness does not exist. This is due to its insubstantiality; consciousness is not a specific entity, but it is a stream of thoughts and data about subjective experience. It is a "function of knowing," a tool which, by its nature, is selective, fluid, and personal; an instrument founded upon logic, which serves to create an inner coherent reality. James represents consciousness as a continuous process. For example, he considers sleep a "time-gap" during which consciousness sinks and remains intact. In fact, upon awakening people are the same person they were before sleep. James' theory of consciousness denotes it as a being most closely related to thought and awareness of oneself in the world during waking moments. It is depicted as a persistent flow of thoughts which sets up a relationship between inner and outside world.

This description is very near the phenomenological one. Indeed, both Husserl and James consider consciousness as a function. ${ }^{12}$ Wilshire maintains that James modifies his perspective in the analysis of consciousness from the behaviorist tradition, in which he begins his study of psychology, toward a properly phenomenological viewpoint. ${ }^{13}$ Even if James falls short of the phenomenological terminology of intentionality, he suggests a definition of consciousness as a flow of pure experience. According to James, consciousness exists just as a function of knowing. "It is supposed necessary to explain the fact that things not only are, but get reported, are known. Whoever blots out the notion of consciousness from his list of first principles must still provide in some way for that function's being carried on. ${ }^{14}$ Consciousness consists in its pure epistemological and flowing relation with the external world. It can be in flux because every unit of experience is fringed by feelings of anticipa- tion, proximity, continuity etc., and it is an epistemological current, because all its perceptual experiences are expressed just on the level of language. ${ }^{15}$

9 Thus, it is here that we might find a common field between James and Husserl, because both seek to describe the experience of consciousness as an absolute realm which antedates every quantitative distinction. As Perry remarks, there is no material anywhere, only data. The entire world is a datum which is made up of two parts, the objective and subjective part, seen retrospectively. ${ }^{16}$ Nevertheless, it is not easy to reach the pure flux of consciousness because of its pureness; when we touch it, it turns into the 
first person. According to James, the pursuit of the original material of pure experience becomes a sort of mythical quest to get beneath even the individual stream of consciousness, to discover the neutral constituents of both psychic and physical reality. Although a pure full return to the world of pure experience is not possible, James suggests that we might attain at least a partial awareness of the relative purity and simplicity of the pre-conceptual flow of perceptual experience. He writes in fact: "All homes are infinite experience." In a similar way, phenomenology postulates a "preempirical origin,' a standpoint apart from experience from which it may be evaluated, surveyed or understood. Both Principles and phenomenological research are characterized by an archaeological strategy. Jamesian and Husserlian methods consist in digging beneath the succeeding strata of conceptual organization to reach the original prestructured field of perceptual experience. In this sense their methods can be compared.

Moreover, according to James, the steps that lead to knowledge are sensation, perception and conception. By means of sensations we have an acquaintance with the facts or rather we become the facts. Attention guides the aim of our sensations and transforms them into perception. In fact, the flow of pure sensations is nothing but an imaginary construct which James invents in order to explain the element of facticity which characterizes our primitive perception. Indeed, perception makes possible the "knowledge about a fact." 17 The third level of knowledge is the level of conception, which focuses on one aspect of the stream and excludes the others. Perception provides the initial relational context upon which conception operates and the sphere to which conception must return. The most important feature of conception consists in its consists in its ability to grasp and recognize the sameness the sameness, which enables us to abstract from the infinite variety of details and to have knowledge about a specific part of reality. 'Knowledge about' describes, defines, tells us what an object is.

11 Even if the early stages of the Principles are characterized by a deliberate evasion from any metaphysical analysis of consciousness and from any epistemological consideration of it, they always turn out to be related to the pure epistemological path of consciousness. ${ }^{18}$ Every step of the life of consciousness is an instrument for its epistemological knowledge. "Knowing must have a vehicle. Call the vehicle Ego, or call it Thought, Psychosis, Soul, Intelligence, Consciousness, Mind, Reason, Feeling, - what you like - it must know." ${ }^{19}$ Therefore, the will must be one of the tools of knowledge that allows the soul to perceive and discover the world. As he wrote: "Now, for instance, the soul manifests its faculty of memory, now of reasoning, now of volition, or again its imagination or its appetite." ${ }^{20}$ Reason is a faculty we have at our disposal in order to create a system of conceptions of our reality. "What the ordinary psychologies call 'ideas' are nothing but parts of the total object of representation." ${ }^{21}$ In his lectures on pragmatism, James frequently asserts that ideas, which are experiential data, become true only in so far as they help us to get into satisfactory relations with the other parts of experience. Like conception, ideas are the result of a living relationship between the subject and the world. Their function is to guide us from one unit of experience to another by diverse routes which are also features of experience. The whole process of knowledge takes place within the confines of the stream of experience. The will, too, is encompassed in this three-step process. It is a useful way to gain perceptive data and to create new conceptions. An idea becomes true by means of a referential process which takes place entirely within the network of experience. The transcendence of an object 
refers simply to the possibility of further determinations of the same object beyond the present field of experience.

\section{a) Husserlian Definition of Consciousness}

12 As Spiegelberg remarks, the chapter of Principles in which James explains his idea of sensation, perception and conception, is filled with notations of Husserl. ${ }^{22}$ Husserl shares with James a common account of the life of consciousness. Like James, Husserl seeks to reach a clear definition of its realm. In Logical Investigations the analysis revolves around consciousness and its pure contents, since it has been reckoned as a source of pure principles of logic. Indeed phenomenology is that method aimed at the clarification of the contents of consciousness in order to found a pure logic. ${ }^{23}$ These aims account for an epistemological definition of consciousness as a pure flow of meanings. In the fifth Logical Investigations he makes a distinction among three definitions of consciousness, all focused on the link between acts and consciousness. To begin with, consciousness is what is merely experienced. ${ }^{24}$ It is the wholeness of all the acts and the utmost reach of its knowledge. It corresponds to a system of acts and to our perception of this system. Husserl's second notion of consciousness merely adds to the first one the idea according to which its immanent components are adequately perceived by an 'inner consciousness' (Gewahrwerden). Every datum is the content of a lived experience (Erlebnis) of consciousness. In the third definition Husserl depicts consciousness as an overall understanding of pure lived experience. This involves an "another experience which requires a new percept" ${ }^{25}$ and it accompanies every perception.

This third conception consists, to a fair degree, of a concentrated analysis of what Husserl called the 'objectifying interpretatio' in his first conception of consciousness. ${ }^{26}$ Husserl now calls this 'objectifying interpretation' the act-matter, and opposes it to the actquality. The matter and the quality of the act together form its intentional essence. Both are immanent components of the intentional act itself. The matter is the component that supplies the 'reference' to an object. Following Husserl, the matter must be that element in an act which first gives it reference to an object, and reference so wholly definite that it does not merely fix the object meant in a general way, but also the precise way in which it is meant. ${ }^{27}$ The matter is what gives consciousness its 'directedness' towards an object, or, in terms of intentionality, it is the 'intending' of the object. There can be several acts directed to the same object, and each of these acts can mean the object in a different way, i.e., each one can be directed to a different property of the object. The matter is the directedness towards an object, and it is the directedness towards one specific property of the object. In general, the matter is the aspect of the act that determines what it is conscious of. In contrast to this, the quality of the act is the aspect that determines the way the act is conscious of the object. The quality "stamps an act as merely representative, judgmental, emotional, desiderative, etc." ${ }^{28}$ A series of acts can have the same matter with only the qualities of the acts changing. I can doubt, assert, wish, question, or be fearful that there are "intelligent beings on Mars"; all these acts have one and the same matter, the "intelligent beings on Mars," with different qualities, the doubting, asserting, wishing, etc.

Husserl conceives consciousness as a realm of pure and absolute rationality which holds a relationship with the outside world by means of its rational tools. ${ }^{29}$ "Das Vernunftbewußtsein ist aber nicht das Bewusstsein überhaupt [...] - denn vielleicht ist [...] 
im wesentlicher Analogie dem theoretischen oder besser überhaupt dem doxischen Vernunftbewußtsein ein axiotisches [...] und praktisches mit mannigfaltigen eigentümlich Gestaltungen beizuordnen." ${ }^{\prime 30}$ Consciousness is a rational sphere which can be modalized according to the several qualities and matters of its acts. Its rationality can be logical, axiological, practical and so forth, because of the direction and contents of its acts. Moreover, all these regions of reason are presented as the rational roots of correspondent theories, such as logic, ethics, axiology. Husserl writes in fact: "Wie der formalen Logik ein System fundamentaler Strukturen des Glaubensbewußtseins (des doxischen, wie ich zu sagen pflege) entspricht und somit eine Phänomenologie und Theorie der formalen Erkenntnis, so ähnlich verhält es sich mit der formalen Axiologie und Praktik hinsichtlich der ihnen prinzipiell zugehörigen Disziplin der Phänomenologie bzw. der Wertungs- und Willenstheorie." ${ }^{31}$ The will is one of the several regions of consciousness and it is one of its tools for understanding and experiencing the outside world.

Every kind of knowledge is the result of the relationship between living consciousness and the external world. In consciousness there is a rational root for every kind of knowledge and ideas are just the product of the activity of consciousness. Every idea is made up of the interpreting act of consciousness and its matter, or in different terms, by its quality and matter. According to Husserl and to James, the idea is a guiding concept resulting from the match between subjective perception and reality. Its structure is a sort of index to recollect every moment of perception and knowledge. Therefore, for both philosophers, every act has an epistemological nuance, because it is tied to the process of knowledge in an active or passive way in order to interpret reality. Every act is not a finished concept, but is, instead, open, like the life of consciousness. Both philosophers stress the original flow of experience of consciousness and make an extraordinary effort to approach the fullness of experience without prejudices with respect to all aspects of givenness in the flow of experience. This philosophic attitude leads them to draw up a definition of consciousness in which the epistemological activity is invasive toward other attitudes. Thus the questions we pose are the following: how do they describe the will and its freedom? Can the will maintain its moral grasp? Can freedom be thought of independently from knowledge or is it just one of the epistemological modes?

\section{The Will in James}

In James the will is described as a particular faculty of consciousness. For James, it is 'an emotional movement, ${ }^{32}$ which acts thanks to memory. Without the performance of previous movements already experienced, no new voluntary movement is possible, but just an involuntary or passive one. "There is a certain a priori reason why the kinaesthetic images ought to be the last psychic antecedents of the outgoing currents, and why we should expect these currents to be insentient." ${ }^{33}$ James holds that the will is motivated just by the anticipatory image of a movement. The motivational core of will is the idea of movements and its different variations. "The bare idea is sufficient, but sometimes an additional conscious element, in the shape of a fiat, mandate, or express consent, has to intervene and precede the movement." ${ }^{34}$ The inner structure of volition seems to be epistemological, because the decision of will is always based on a bare idea and sometimes its decision is not even necessary. This is due to the telos of every volition; indeed it consists in the representation of what memory can recall. The will takes its 
decision on the basis of what is represented. From this it might be inferred that the key step of every act of will is the representation of the previous movement. Although the kinaesthetic moment is the source of what will is going to do, this movement has to be represented before every decision is taken. Free will can be accounted for as a habit of an ideo-motor action, as Cotkin ${ }^{35}$ points out; but the very core of this movement is a well known representation of the reasons and consequences of this deed. The example James posed is clear. If we lie in a warm bed in a cold morning, we decide to wake up because "a fortunate lapse of consciousness occurs; we forget both the warmth and the cold; we fall into some revery connected with the day's life, in the course of which the idea flashes across us, "Hollo! I must lie here no longer" - an idea which at that lucky instant awakens no contradictory or paralyzing suggestions, and consequently produces immediately its appropriate motor effects. It was our acute consciousness of both the warmth and the cold during the period of struggle, which paralyzed our activity then and kept our idea of rising in the condition of wish and not of will. The moment these inhibitory ideas ceased, the original idea exerted its effects." ${ }^{36}$

17 The education of consciousness by repeated acts affects our decision to wake up and to break down the flow of our desires and competing ideas. The conception of duty leads us to jump out of the bed and to resolve the struggle between opposite ideas. We know what we have to do because we have been taught to follow the conception which has better implications. There is not the effort of any feeling, but reasoning activity. "The terminus of the psychological process in volition, the point to which the will is directly applied, is always an idea. [...] The only resistance which our will can possibly experience is the resistance which such an idea offers to being attended to at all. To attend to it is the volitional act, and the only inward volitional act which we ever perform." ${ }^{37}$ When we want to do something, we give our consent to a specific representation of an idea. The freedom of will consists in the act of a choice between different representations. Instinct and feeling seem to be regulated by knowledge. The fiat of our will is, according to James, generated by the consent to a specific conception which is at the basis of an idea. Hence if willing means 'sustaining a representation, ${ }^{38}$ which is the very domain of will? What does freedom mean?

In James willing terminates with the prevalence of the idea. Whether the act follows or not is a matter that is quite immaterial, so far as the willing itself goes. I want to write, and the act follows. ${ }^{39}$ Freedom is not taken into consideration because the epistemological and psychological sides of his analysis prevail over the moral one. Freedom is considered just as a sort of an "effort of attention" to consent to a specific idea. Both will and its freedom are reduced to the activity of attention and memory. "Freedom - James writes - is the very activity of attention. The essential achievement of the will, in short, when it is most 'voluntary,' is to attend to a difficult object and hold it fast before the mind. The so-doing is the fiat." ${ }^{41}$ Attention is the index of the mobile mastery of consciousness in the entire cycle of its activity: a) in the perceptual structuring of the flow of experience b) in the projection of patterns of meaning; c) in the natural culmination of these projects in concrete corporeal activity. In this sense freedom is not considered as an actual property of will, but as a modalization of the attention which has to zero in on different representations of objects. Freedom belongs more to the epistemological activity of consciousness than to the practical activity. From a psychological point of view free will is not a consistent faculty because it is just the fiat of an attention linked up to reasonable representations experienced by the mind. ${ }^{42}$ The natural consequence of this analysis is 
both to subordinate the will to an epistemological mechanism and to make it an illusion or a dogmatic faculty.

In an excerpt, which dates back to 1870 , James reaches the same conclusions from a biographical point of view: "I think that yesterday was a crisis in my life. I finished the first part of Renouvier's second 'Essais' and see no reason why his definition of Free Will 'the sustaining of a thought because I chose to when I might have other thoughts' - need be the definition of an illusion. At any rate, I will assume for the present - until next year - that it is no illusion. My first act of free will shall be to believe in free will." ${ }^{\prime 3}$ Free will is mostly an illusion which can be rationalized by an act of belief. Freedom is an idea of reason we have to trust in, but which cannot be proved. The epistemological support of will falls short just when it has to explain the rational foundation of free activity. The main foundation of free will consists in its submission to the strength of belief. There is, accordingly, no domain for a pure moral activity. If freedom of will is fixed by an act of belief or by a dogma, the resulting ethics will be dogmatic or religious. The will is lacking in its moral component whenever it is linked up to the epistemological activity of a subject or to a dogmatic or religious choice, because its freedom is accounted for just as an 'illusion' or as an automatic response to a representation.

\section{a) The Will in Husserl}

What strikes the attention of the reader is the likeness between the 'ethical' consequences of two different philosophical studies of consciousness. Like James, Husserl develops an analysis of consciousness in which the epistemological side of consciousness prevails over the others. Both give a definition of will in which the realm of will is nearly neutralized by the epistemological activity. Yet the moral thought they deal with is different. Whereas James delineates an ethical thought which is based on the dogma or 'illusion' of freedom, Husserl provides for an ethical discipline in which there is no need for freedom because it is almost replaced by an axiological and epistemological weighing up. Every ethical choice is in fact based on the mathematical calculation of values and logical arguments which allow one to support it. ${ }^{44}$

In Husserl one of the first analytical descriptions of the will can be found in the ethical lectures of 1914. These lectures are the result of the ethical research that had been carried out by Husserl since 1902. In his Husserls Phänomenologie des Willens, Melle ${ }^{45}$ sketches out the main influences on Husserl's work. Namely, he refers to the work of James ${ }^{46}$ and Ehrenfels. ${ }^{47}$ The former holds that the main characteristic of will is attention and its fiat, that is, the 'act of mental consent.' The latter construes the act of will not as a founding act, because it is just a pretension (Forderung) of something and thus it needs the representative acts of logical reason.

The description of will of 1914 is affected by these two philosophical positions. The will is considered as a parallel modalization of consciousness. It represents the grasp of consciousness of willing or doing something. It is described as a logical act that belongs to the realm of operating. Its distinctive characteristic is that of "fiat!" 48 Its fiat is a creative and distinctive feature by which the act of will yields a new reality. Every act of will is at the basis of an action that modifies reality in a certain way or adds new elements to it. The thesis of will (Willensthesis) is mainly a position of realization and creation. This activity itself can be thought of by following different modes: "Für alle Abwandlungen des 
Urteils-bewußtseins finden wir so und apriori parallele Abwandlungen des Willensbewußtseins." 49

Husserl maintains the existence of a parallelism between logical and practical reason. These two kinds of reason can modalize themselves in the same ways. It is possible, in fact, that we can desire something with conviction or doubt, with desire or fear or with many other expressions. These modes correspond to the different modalities of judgment of logical reason, such as, for example, those of assertions or questions or doubts and so forth. There are a great number of a priori rational expressions of will and logical reason. The absolute rationality of these remains the same, although they are different and realize themselves in a human context. Nevertheless, the symmetry between practical and logical reason is not possible at all, as they have similar ways to express themselves in the world. Yet the a priori and rational structures of will can work only with the support of logical reason. As we said before, the will depends on logical grasp to interpret reality and represent it. "Wollungen sind fundiert durch doxischen Thesen und zugleich durch Thesen der Sphäre der Wertungen. Fundierte Thesen haben nicht nur Richtigkeit überhaupt und in dem Sinn, daß sie ihre doxische, axiologische, praktische Wahrheit bzw. Unwahrheit habe, sondern sie 'richten' sich auch nach ihren Fundament-Thesen." ${ }^{50}$

Following Husserl, even if the will can generally be considered parallel to logical reason, it needs the support of logical reason to found its acts. Indeed, it is necessary to know an object, in order to refer to it. Husserl, too, considers representations to be the basis of every act of will. The quality and the matter which make up every act of consciousness are linked in the epistemological representation of logical reason. ${ }^{51}$ Acts of will are strictly connected to the reason of thinking, because we cannot do anything if we do not know the things toward which we act. "Dabei setzt jeder Wille nicht nur überhaupt Vorstellung des Gewollten voraus, sondern er hat notwendig eine umfassende Vorstellungsunterlage und [...] das Gewollte auch eine Glaubensunterlage bezogen auf reales Sein." 52

When we want something, we have to represent and know our object. The will depends necessarily on logical reason both for the expression of its intentions and for its realization. In this context the definition of will is in harmony with one used in the first and second editions of Logische Untersuchungen. ${ }^{53}$ Here, in fact, Husserl wrote that there is not a parallelism between logical and practical reason, because the latter depends on the former in its pure and rational activity. This is not completely an intentional kind of reason, ${ }^{54}$ because its acts cannot represent their objects. It refers to its objects usually in an impulsive or instinctive way. ${ }^{55}$ The realization of will is, in fact, reliant on logical reason and on its predicative or representative "voice." ${ }^{56}$ Without the representations of predicative reason, the will cannot represent the objects of its volitions to itself. Thus, the reason of pure consciousness is logical. On the contrary, the reason of will is just a psychological reason that can be purely rational only by means of the 'objectivating' help of logical reason. Moreover, the values supplied by axiological reason provide the rational orientation of any choice. This means that every logical representation in fact can be placed in a graduated table of values and the best fiat will be based on the accomplishment of the best value.

26 As for the Husserlian ethical lectures of 1914, freedom is not mentioned. Differently from James, the response of will is not only an automatic kinaesthetic movement, but also a choice resulting from the weighing of considerations by the subject. Yet, like James, Husserl hints at freedom, without mentioning it, with regard to the moment of fiat. 
Freedom, in fact, consists in the capacity of will to consent or not to a specific doxic representation of logical reason. The Entscheidung consists in an axiological weighing up (Wertabwägung) of the objects experienced and represented by the predicative voice of logical reason. ${ }^{57}$ Freedom is connected to the logical property of reason and it is not placed in the realm of instinct or emotions. "Der Wille geht auf Wirklichkeit, nicht ideale, sondern individuelle, reale Wirklichkeit. [...] Dabei setzt jeder Wille nicht nur überhaupt Vorstellung der Gewollten voraus, sondern er hat eine Glaubensunterlage bezogen auf reales Sein. ${ }^{158}$ It exists as acknowledgment of the rationality (epistemological or logical rationality) of a motivation" "So gibt es ein völlig ohne Begründungsunterlage erfolgendes Wollen und ein durch Gründe motiviertes, ein Wollen in Form klarer praktischer Vernunft und ein Wollen, das Vernunftmotive einschließt, aber unklare usw. [...] Das Wollen im ursprünglichen Sinn ist das Analogon des Gewissheit, ich setze schlechthin und praktisch als seinsollend: 'Es werde!'." ${ }^{60}$ Freedom can be considered as the final granting of an act. It is what lets the act be as it has to be. It is the axiological and epistemological choice related to what logical reason represented.

Both philosophers think about will in an epistemological way. Its activity is close to logical rationality or representative ideas. Both James and Husserl seek to carry on just a genetic analysis, free from any epistemological implications, but they fall into an epistemo-logical idea of morality which leaves little room for any voluntary choice. Ethics cannot exist without the idea of freedom. Therefore, the subsequent moral writings of James and Husserl are the consequences of these philosophic positions. In Will to Believe morality is based on the act of belief and it is above all a kind of religious morality. In the Husserlian ethical lectures of 1920, there is not a pure moral system, but an epistemological analysis of the inner structure of the ethical deed. Therefore, according to our study, in James and Husserl there are not only many similarities but also a common theory of will which excludes an idea of freedom which is autonomous from epistemological reason. It follows that morality is above all a morality of consent to believe or to follow what reason thinks.

To conclude it is worthwhile to emphasize the following points:

as though James and Husserl belong to different philosophic movements, they carry on similar pathways in their analysis of consciousness;

the definition of will they work out is deeply linked to the epistemological layer of the activity of consciousness;

these reasons led James to pose freedom as an act of belief of free will and Husserl to subordinate the will to the activity of logical reason. Both reduce the foundation of pure morality to being in virtue of a dogmatic or automatic choice.

\section{BIBLIOGRAPHY}

BENOIST J., (2005), “Phenomenology or Pragmatism?," Pragmatism, Critical Concepts in Philosophy, vol. 2, 89-112.

COTKIN G., (1990), William James, Public Philosopher, Baltimore-London, John Hopkins UP. 
EHRENFELS, C., (1887), Über Fühlen und Wollen. Eine Psychologische Studie, Vienna.

EDIE M. J., (1965), An Invitation to Phenomenology. Studies in the Philosophy of Experience, Chicago, Quadrangles Books.

GURTWISCH A., (1965), Phenomenology: Its Genesis and Prospect, New York, Harper and Row.

HUSSERL E., (1986), Aufsätze und Vorträge. 1911-1921, The Hague, Martinus Nijhoff.

HUSSERL E., (1950), Ideen zu einer reinen Phänomenlogie und phänomenlogischen Philosophie. Erstes Buch: Allgemeine Einführung in die reine Phänomenologie, The Hague, Martinus Nijhoff.

HUSSERL E., (1975; originally published in 1900), Logische Untersuchungen. Erster Teil. Prolegomena zur reinen Logik, The Hague, Martinus Nijhoff.

HUSSERL E., (1984; originally published in 1922), Logische Untersuchungen. Zweiter Teil.

Untersuchungen zur Phänomenologie und Theorie der Erkenntnis, The Hague, Martinus Nijhoff.

HUSSERL E., (1988), Vorlesungen über Ethik und Wertlehre. 1908-1914, The Hague, Kluwer Academic Publishers.

JAMES W., (1904), “Does Consciousness Exist?," Journal of Philosophy, Psychology, and Scientific Methods, 1, 477-91.

JAMES W., (1981; originally published in 1890), The Principles of Psychology, Cambridge, Harvard University Press.

MELLE U., (1992), “Phänomenologie des Willens,” Tijdschrift voor Filosofie, 54, 280- 304.

PERRY R. B., (1936) The Thought and Character of W. James, Boston, Little Brown and co.

Rosenthal S. B. \& P. L. BOURGeoIs, (1980), Pragmatism and Phenomenology: A Philosophic Encounter, Grüner, Amsterdam.

schuHMAnN K., (1977), Husserl-Kronik. Denk- und Lebensweg Edmund Husserls, Den Haag, Nijhoff, 1977.

SPIEGELBERG E., (1982), Phenomenological Movements, The Hague, Springer.

THAYER H. S., (1968), Meaning and Action, New York, Bobbs-Merrill.

WELCH P., (1965), The Philosophy of Edmund Husserl, New York, Octagon Books.

WILSHIRE B., (1979), William James and Phenomenology: A Study of "The Principles of Psychology," New York, AMS Press.

\section{NOTES}

1. Rosenthal \& Bourgeois, (1980: 12); Benoist (2005: 90).

2. Gurtwisch (1965: passim).

3. Thayer (1968: IX-X).

4. Edie (1965: 8).

5. Schuhmann (1977: 172).

6. Schuhmann (1977: 41).

7. Schuhmann (1977: 32).

8. Schuhmann (1977: 320).

9. Schuhmann (1977: 363).

10. James (1890: 224-5). 
11. James (1904: 477).

12. James (1904: 477).

13. Wilshire (1979: passim).

14. James (1904: 477).

15. James (1890: 245): "We ought to say feeling of and, a feeling of it, a feeling of but and a feeling of by, quite as readily as we say a feeling of blue or a feeling of cold. Yet we do not: so inveterate has become our habit of recognizing the existence of substantive parts alone that language refuses to lend itself to any other use."

16. Perry (1936: 366).

17. James (1890: 2).

18. James (1890: 218).

19. James (1890: 363).

20. James (1890: 11).

21. James (1890: 568).

22. Spiegelberg (1982:113-4).

23. Husserl (1922: 3).

24. Husserl (1922: 567).

25. Husserl (1922: 543).

26. Welch [(1965:74)] claimed that Husserl rejected the first two notions of consciousness. But this belies the text, for not only does Husserl refrain from making any criticism of these first two notions of consciousness, but his third notion of consciousness is actually an explication of one of the components of his first conception of consciousness. As we mention below, the "objectifying interpretation" is the "matter" of the third conception of consciousness (cf. Husserl 1922: 589). The reason why Husserl spends the major portion of the Investigations on the third conception of consciousness, rather than on the first two, is explained on pages 533-5. Here Husserl says that he is interested in the nature of "meaning-experiences," and these "meaning-experiences" fall within the genus of acts, and it is only the third conception of consciousness that defines consciousness as an act. In Husserl's later works, this intentional essence came under the concept of the noesis, (cf. Husserl 1913: 362). At the time of the Logical Investigations, Husserl had not yet reached the concept of a noema.

27. Husserl (1922: 589).

28. Husserl (1922: 586).

29. Nevertheless, after the introduction of genetic method he introduces a passive and active definition of consciousness.

30. Husserl (1986: 147).

31. Husserl (1988: 4).

32. James (1890: 487).

33. James (1890: 496).

34. James (1890: 522).

35. Cotkin (1990: 68).

36. James (1890: 525).

37. James (1890: 567).

38. James (1890: 566-7).

39. James (1890: 560).

40. James (1890: 563).

41. James (1890: 561).

42. James (1890: 552): “The only comprehensible and reasonable motives for action, the only motives on which we ought to act. That is an ethical proposition, in favour of which a good deal may be said. But it is not a psychological proposition; and nothing follows from it as to the motives upon which as a matter of fact we do act." 
43. James (1870: 47).

44. Husserl (1988: 70-101).

45. Melle (1992: 280-325).

46. James (1950: 560).

47. Von Ehrenfels (1887: 75)

48. Husserl (1988: 107).

49. Husserl (1988: 115).

50. Husserl (1988:127).

51. Husserl (1984, 426-31).

52. Husserl $(1988,109)$.

53. Husserl (1975: 382).

54. Husserl $(1975,367)$.

55. Husserl (1984: 388, 405).

56. Husserl (1988: 69).

57. Husserl (1988: 36, 126).

58. Husserl (1988: 109).

59. Husserl (1988: 139).

60. Husserl (1988: 113-4). 